\title{
Tarihçilik Açısından Büyük Taarruz Sahasının Ekoturizm İle İlişkilendirilmesi
}

\begin{abstract}
Songül Keçili*
Afyon Kocatepe Üniversitesi, Sosyal Bilimler Enstitüsü, Afyon.

\section{$\ddot{O} z$}

26 Ağustos 1922 sabahı başlayan Büyük Taarruz'un ilk beş gününde, Yunan kuvvetlerinin çoğu etkisiz hale getirilmiştir. Kocatepe, Büyükkalecik, Küçükkalecik, Afyonkarahisar, Sinanpaşa ve Dumlupınar üzerinde başarılı olan hareket, 30 Ağustos Başkomutanlık Meydan Muharebesiyle taçlandırılmıştır. Sonrasında Yunan Ordusunu takip eden Türk Ordusu, İzmir'e kadar olan bölgeye doğru ilerlemiştir. Kazanılan zaferler Türk Tarihi açısından önemli bir yer teşkil etmektedir. Bununla birlikte Büyük Taarruz; Kocatepe ile Dumlupınar arasında kalan bölgeyi kapsamaktadır. Ekoturizm yerel halka sosyo-ekonomik fayda sağlayan doğaya, çevre açısından sorumluluk duygusu geliştiren seyahat ve ziyaret şeklidir. Bu sosyo-kültürel faaliyet genel itibariyle; gelir seviyesi üst düzeyde olan insanlar ve orta sınıf tüketiciler tarafından talep edilmektedir. Aynı zamanda insanların bakış açısını, beğenisini geliştirerek, eğitim olanağ getirilerini ortaya çıkaran, çevreye karşı bilinçli bireyler yetiştirilmesini amaçlamaktadır. Bunların yanı sıra savaş alanları turizmini de kapsayan Ekoturizm, Kocatepe'den Dumlupınar'a kadar düzenlenecek turistik etkinliklerle hem yerel-milli hem de maddimanevi katkılar sağlayacaktır. Tebliğimizin amacı; tarih, turizm ve diğer bazı farklı bilimlerden hareketle disiplinler arası bilimsel bir çalışma ortaya koymaktır. Araştırmamızda; arşiv belgeleri, kanunlar, süreli yayınlar, hatıratlar ve telif eserlerden yararlanılarak Büyük Taarruz sahasının Ekoturizm açısından önemi ilim camiasına sunulacaktır.
\end{abstract}

Anahtar Kelimeler: Büyük Taarruz, Afyonkarahisar, Turizm, Ekoturizm, Çevre.

\section{Associating the Region of the Great Offensive with Ecotourism from the Perspective of History}

\begin{abstract}
Most of the Greek Army were put out of action on the first five days of the Great Offensive starting on the morning of the 26th of August 1922. This successful offensive on Kocatepe, Büyükkalecik, Afyonkarahisar, Sinanpaşa and Dumlupınar, has been crowned with the Battle of Dumlupinar. The Turkish Army chasing the Greek Army have moved forward the region until Izmir. The Great Offensive, which plays an important role in Turkish History, has occurred in the region between Kocatepe and Dumlupinar. Ecotourism is a form of responsible travel regarding of the environment to the natural area that provides socio-economic benefit to local people. It is a socio-cultural activity which is usually preferred by people with a high level of income and middleclass consumers. It also provides educational opportunity by developing a point of view regarding of ecotourism, and receiving appreciation of visitors. Moreover, it aims raising environment-friendly individuals by dealing with different ideas and research which reveal yield of the local economy. Ecotourism, including battlefield tourism, will also support both local-national
\end{abstract}

\footnotetext{
*Bu Araştırma; Çanakkale Onsekiz Mart Üniversitesi tarafından düzenlenen ISEEP 2017 VIII. International Symposium on Ecology and Environmental Problem sempozyumunda sözlü olarak sunulan tebliğin genişletilmiş ve zenginleştirilmiş halidir.
}

*Yazışma adresi. Email: songulkecili@gmail.com 
and moral-material benefits via the touristic activities which will be organized from Kocatepe to Dumlupinar. The aim of this paper is to suggest an interdisciplinary scientific research based on history, tourism and other sciences related to the topic. The organization of the paper is composed of archival resources, laws, periodicals, memories and copyrighted works. With this paper, the importance of the Great Offensive regarding of ecotourism will be presented to the scientific community.

Keywords: The Great Offensive, Afyonkarahisar, Tourism, Ecotourism, Environment.

\section{Gíriş}

Türk milletinin Milli Mücadele'de düşman karşısında göstermiş olduğu mücadelenin sonuçlanmasında etkili olan Büyük Taarruz Türk ordusunun kazanmış olduğu önemli bir zaferdir. ${ }^{1}$ Afyonkarahisar'ın bağımsızlı̆̆ın ve Cumhuriyetin kazanıldığ1 topraklar olması itibariyle tarihi bir önem arz etmesi yanında giderek ağırlığı hissedilen Ekoturizm açısından da değerlendirilebilecek bir konumda olduğu bilinmektedir.

Bütün tarihi olaylar coğrafi bir mekan içinde geçer. Mekanın tasviri olayın değerlendirilmesi açısından çok önemlidir. Coğrafi şartlar tarihe şekil verir ve gelişmesine yardım eder². Yapılan bir savaşın nasıl bir bölgede geçtiği bölgenin fiziki yapısı savaşın gidişatı açısından önemlidir.

Afyonkarahisar ili sınırları içerisinde kalan Kocatepe savaş alanı başta bütün ülke insanları ve özellikle de bölge halkı için mistik, kahramanca mücadelenin verildiği gerçek bir savaş alanıdır. Bu alandaki birçok yer verilen mücadele ve ortaya konulan zaferle doğru orantılı efsanevi bir yapıya kavuşmuştur. Bunlar aynı zamanda insanlık tarihinin en kanlı onur mücadelesinin verildiği ve savaşın coğrafi mekana işlendiği alanlardan biri olmuştur. Mücadelenin verildiği bu alan Kocatepe bölgesinde, Kocatepe, Büyükkalecik, Kurtkaya Mevkii, Sivritepe, Beytepe, Erkmentepe, Kaleciksivrisi, Hıdırlıktepe, Otluktepe, Tınaztepe ve Çiğiltepe bölgeleridir³.

Türkiye bölünmez bir bütündür ve parçalanamaz. İster siyasi ister coğrafi olsun parçalanması dahi düşünülemez. Misak-ı Milli sınırları içerisinde kalan büyük Türkiye sınırlarına kavuşmalıdır. Büyük Türkiye'nin sınırlarını doğal ve kültürel coğrafya belirlemiştir ${ }^{4}$.

\footnotetext{
${ }_{1}$ Milli Mücadele ve Büyük Taarruz hakkında genel değerlendirmeler için bk. İsmet Görgülü, Büyük Taarruz, Genelkurmay Yay., Ankara 1992; İbrahim Artuç, Başkomutan Meydan Muharebesi, Büyük Taarruz, 7. b., Kastas Yay., İstanbul 2008; Sebahattin Selek, Milli Mücadele: Büyük Taarruz'dan İzmir'e, Cumhuriyet Gazetesi Yay., İstanbul 1997; Uğur Üçüncü Büyük Taarruz, Altın Post Yay., İstanbul 2012; A. Turan Oflazoğlu, Mütarekeden Büyük Taarruza, İz Yay., İstanbul 2011.

${ }^{2}$ Mübahat Kütükoğlu, Tarih Araştırmalarında Usul, Türk Tarih Kurumu Yayınları, Ankara 2011, s. 11.

${ }^{3}$ Faruk Alaeddinoğlu, "Kocatepe'nin Türk Kültür Turizmi Açısından Önemi”, Atatürk ve Büyük Taarruz Kahramanlarına Armağan, (Ed: Gürsoy Şahin), Afyon Kocatepe Üniversitesi Yayınları, Afyonkarahisar 2010, s.439.

4 Ramazan Özey, “Misak-1 Milli Sınırları İçinde Kalan Büyük Türkiye'nin Coğrafi Şahsiyeti”, Yeni Türkiye Misak-1 Milli Özel Sayısı, XXIII, S. 93, Yeni Türkiye Stratejik Araştırma Merkezi Yayınları, Ankara OcakŞubat 2017, s.787.
} 
Başkomutan Gazi Mustafa Kemal'in 26 Ağustos 1922 sabahı başlayan Büyük Taarruz Hareketi, Afyon-Dumlupınar Meydan Muharebesinin son evresine rastlayan ve bizzat kendisinin sevk ve idare ettiği 30 Ağustos 1922 Başkumandan Muharebesinde Yunan asıl kuvvetlerinin çoğu etkisiz hale getirilmiştir ${ }^{5}$. Üç yıldır devam eden İstiklal Mücadelesinde Türk ordularına hedef olarak Akdeniz gösterilmiştir. Atatürk'ün bu tarihi direktifi Türkiye Büyük Millet Meclisi orduları tarafından dünya harp tarihinde eşine az rastlanan bir hızla bir yıldırım harbi olarak geçmiş, Türk ordusunun 9 Eylül 1922'de İzmir'e girmesiyle büyük bir zafer coşkusuna dönüşmüştür. Ordu millet dayanışması ile başlatılan topyekun mücadele esasına psikolojik harekatın her türlü yöntemleri uygulanarak 30 Ağustos 1922 tarihindeki bu büyük zafere uzanan yol açılmıştır'. Milli Mücadele'nin sonunda askeri zaferin verdiği güçle Lozan Antlaşması'nın imzalanması sonucunda yeni Türkiye külleri üzerinde doğduğu devleti geri bırakan ve sonunda yok olma noktasına getiren bütün bağlardan kurtulmuş oldu. Bu durum Türk mucizesi olarak da isimlendirildi. ${ }^{7}$

Ekoturizm eğlenmeyi, doğayı ve kültürel kaynakları anlayarak bu kaynakların korunmasını destekleyen az sayıda ziyaretçi etkisi olan ve yerel halka sosyo-ekonomik fayda sağlayan her türlü bozulmamış doğal alanlara çevresel açıdan sorumluluk duygusunu geliştiren seyahat ve ziyaret şeklidir. Başka bir değişle doğal çevre ile turizm faaliyetini birbirine yakınlaştıran çevrenin olumsuz etkilenmesi konusunda sorumluluk duygusu ile hareket etme esasına dayalı turizm faaliyetidir. Bu sosyokültürel faaliyet genel itibariyle; gelir seviyesi üst düzeyde olan insanlar ve orta sınıf tüketiciler tarafından talep edilmektedir. Aynı zamanda insanların bakış açısını, beğenisini geliştirerek, eğitim olanağı sağlamaktadır. Farklı fikir ve çalışmalar ortaya

\footnotetext{
${ }^{5}$ Bu alanla ilgili 2015 yılında "T.C. Kültür ve Turizm Bakanlığı, Eskişehir Kültür Varlıklarını Koruma Bölge Kurulu'nun kararına istinaden Kültür ve Turizm Bakanlığı Kültür Varlıkları ve Müzeler Genel Müdürlüğü Eskişehir Kültür Varlıklarının Koruma Bölge Kurulu Müdürlüğü, Doğa Koruma ve Milli Parklar Müdürlüğ̈̈'ne 25.03.2015 tarih ve 1034 sayılı yazısıyla konuyu bildirmiş bunun üzerine Orman ve Su İşleri Bakanlı̆̆ı V. Bölge Müdürlüğ̈̈'nün 12.11.2015 tarihli, 88570880-405-228747 sayılı talebi üzerine Afyon Kocatepe Üniversitesi Rektörlüğü'nden Kültür Varlıklarını Koruma Bölge Kurullarına gönderilmek üzere bilimsel rapor ve gerekli bilgi/belgenin hazırlanması amacıyla" Prof. Dr. Mustafa Güler, Doç. Dr. Turan Akkoyun, Yrd. Doç. Dr. Mustafa Karazeybek, Yrd. Doç. Dr. Ümit Emrah bilirkişi olarak görevlendirilmiş Genelkurmay ATASE Arşivi ile telif eserler üzerinde yapılan araştırmanın sonucu bir rapor halinde 29 Şubat 2016 tarihinde teslim edilmiştir. Düzenlenen akademik bilirkişilik raporu gerekli mercilerden geçtikten sonra "26 Ağustos 1922'de başlayıp 30 Ağustos 1922'de son bulan muharebeler ile doğrudan alakalı olan milli park sınırları içerisinde bulunması azami ehemmiyet gösteren bazı sahaların milli parka dahil edilmesi gerektiği, bunun yanında muharebe ile alakası bulunmayan bazı sahaların milli sınırların dışına çıkarılması gerektiği anlaşılmıştır. ... Bölge halkının da yakından bildiği ve vatandaşların evlerinin bulunduğu muharebelerle alakası bulunmayan köy yerleşik alanları, milli park sınırları dışna çıarılmıştır. Böylece milli park sınırları parçalı hale getirilerek yaşanan problemler ortadan kaldırılmıştır. Yerleşim yeri olup da tarihi değer taşıyan alanlar ise milli park sınırları dahilinde bırakılmıştır." "Başkomutan Tarihi Milli Parkı Sınırları Değişti", Kocatepe, 30 Aralık 2016; "Başkomutan Tarihi Milli Parkı Sınır Değişikliği", Haber Türk, 30 Aralık 2016.

${ }^{6}$ Zekeriya Türkmen, "Büyük Taarruz Harekatı", Atatürk ve Büyük Taarruz Kahramanlarına Armağan, (Ed: Gürsoy Şahin), Afyon Kocatepe Üniversitesi Yayınları, Afyonkarahisar 2010, s.143.

7 Saime Yüceer, "Bir Ütopyanın Gerçekleşmesi: Tam Bağımsız Türkiye ve Misak-ı Milli", Yeni Türkiye Misak-1 Milli Özel Sayısı, XXIII, S. 93, Yeni Türkiye Stratejik Araştırma Merkezi Yayınları, Ankara OcakŞubat 2017, s.148.
} 
koyarak, yerel ekonominin getirilerini ortaya çıkaran, çevreye karşı bilinçli bireyler yetiştirilmesini amaçlamaktadır. Bunların yanı sıra savaş alanları turizmini de kapsayan Ekoturizm, Kocatepe'den Dumlupınar'a kadar düzenlenecek turistik etkinliklerle hem yerel-milli hem de maddi-manevi katkılar sağlayacaktır ${ }^{8}$. "Afyonkarahisar ilinin turizm potansiyelinin yüksekliği"9 zaten dikkat çekmektedir.

\section{A. COĞRAFYANIN SAVAŞLAR ÜZERINDEKI ÖNEMI}

\section{Büyük Taarruz Sahası ve Fiziki Yapısı}

Her şeyden önce Afyonkarahisar, coğrafi konumu itibariyle önemli bir yerde bulunuyordu. Ülkemizin Batı Anadolu'ya açılan kapısı durumunda olup kara ve demir yolu ulaşımında bölgenin kavşak noktasında bulunmaktadır. Ulaşımdaki bu önemli konumu şüphesiz ekonomisine canlılık getirmiş, iktisadi hayatında etken olmuştur ${ }^{10}$.

Gazi Mustafa Kemal, Büyük Taarruz başlangıcındaki genel durumu şöyle anlatıyor: "Baylar, artık Büyük Taarruzdan söz etmek zamanı geldi. Bilirsiniz ki Sakarya Meydan savaşından sonra düşman ordusu büyük ve kuvvetli bir grupla Afyonkarahisar - Dumlupınar arasında bulunuyordu. Bir başka kuvvetli grubu ise Eskişehir bölgesinde idi. Bu iki grup arasında yedek kuvvetler vardır. Sağ yanını Menderes bölgesinde bulundurduğu kuvvetlerle sol yanında İznik göl Kuzey ve Güneyindeki kuvvetleri ile koruyordu. Denilebilir ki düşman cephesi Marmara'dan Menderese kadar uzanıyordu"11. Mustafa Kemal bu sözleriyle savaşın yapıldığ 1 sahanın büyüklüğünü önemli bir vurgu yapmaktadır.

Büyük Taarruz zaferinden sonra Türkiye ile Yunanistan arasındaki sınır, 24 Temmuz 1923 Lozan Antlaşması ile çizilmiştir. Türkiye ile Yunanistan kara sınırı toplam uzunluğu 212 km'yi bulmaktadır. Kara sınırı, Meriç ırmağının en derin yerini takip eder. Kapıkule sınır kapısı yakınlarında, Bulgaristan ile Türkiye sınırı birleşir ${ }^{12}$.

\section{Büyük Taarruz Zaferi}

Her şeyden önce, Misak-1 Milli Beyannamesi, Birinci Dünya Savaşı içindeki bazı siyasi ve askeri gelişmeleri bahane ederek Osmanlı Devleti'ni parçalamak ve böylece tarihi “Şark Meselesi” ni sona erdirmek isteyen İtilaf Devletleri (İngiltere, Fransa, İtalya ve Yunanistan)'nin Ocak 1919'da başlayan Paris Barış Konferansı sürecinde Türkiye'nin geleceğiyle ilgili birtakım kararlar almaya çalıştıkları bir ortamda,

\footnotetext{
8 Yunus Arslan, "Erdek ve Çevresinin Ekoturizm Açısından Değerlendirilmesi”, Balıkesir Üniversitesi Sosyal Bilimler Enstitüsü Dergisi, VIII, S. 13, Mayıs 2005, s.31-32.

9Gamze İçlek vd. "Ayazin Örenyeri'nin Ekoturizm Açısından Değerlendirilmesi", Karabük Üniversitesi Sosyal Bilimler Enstitüsü Dergisi, Özel Sayı 3, 2017, s. 146.

${ }^{10}$ Aytaç Taşyürek, “Ulusal Kurtuluş Savaşında ve Cumhuriyet Döneminde Afyon”, Tarih İçinde Afyon 1982, Afyon Müzelerini Eski Eserlerini ve Güzel Sanatlarını Sevenler Derneği Yayını-2, Özen Matbaası, Afyon 1983 s. 50.

${ }^{11}$ Taşyürek, a.g.m., s. 47.

12 Özey, a.g.m., s. 773.
} 
Türkiye'nin barış şartlarını içeren bir program idi. Aynı zamanda da İtilaf Devletlerine yönelik esaslı bir siyasi mesajdır ${ }^{13}$.

17 Şubat 1920 tarihinde Türk ve dünya kamuoyuna duyurulan Ahd-1 Milli (Misak-1 Milli) Beyannamesi şöyledir:

- Devlet-i Osmaniye'nin münhasıran Arap ekseriyetiyle meskun olup 30 Teşrin-i evvel 1918 tarihli mütarekenin hin-i akdinde muhasım orduların işgali altında kalan aksamının mukadderatı ahalisinin serbestçe beyan edecekleri araya tevfikan tayin edilmek lazım geleceğinden, mezkur hatt-1 mütareke dahil ve haricinde dinen, örfen (veya ırken), emelen müttehit ve yekdiğerine karşı hürmet-i mütekabile ve fedakarlık hissiyatıyla meşhun ve hukuk-1 ırkıye ve içtimaiyeleriyle şerait-i muhitiyelerine tamamiyla riayetkar, Osmanl1-İslam ekseriyetiyle meskun bulunan aksamin heyet-i mecmuası hakikaten veya hükmen hiçbir sebeple tefrik kabul etmez bir küldür.

- Ahalisi ilk serbest kaldıkları zamanda ara-yı ammeleriyle Anavatana iltihak etmiş olan elviye-i selase için lede'l-icap tekrar serbestçe ara-yı ammeye müracaat edilmesini kabul ederiz.

- Türkiye sulhuna talik edilen Garbi Trakya vaziyet-i hukukiyesinin tespiti de sekenesinin kemal-i hürriyetle beyan edecekleri araya tebaan vaki olmalıdır.

- Makam-1 Hilafet-i İslamiye ve Payitaht-1 Osmaniye olan İstanbul şehriyle Marmara denizinin emniyeti her türlü halelden masun olmalıdır. Bu esas mahfuz kalmak şartıyla Akdeniz ve Karadeniz boğazlarının ticaret ve münakalat-1 alakadar devletlerin müttefikan verecekleri karar muteberdir.

- Düvel-i İtilafiye ile muhasımları ve bazı müşarikleri arasında takarrür eden esasat-1 ahdiye dairesinde ekalliyetler hukuku memalik-i mütecaviredeki Müslüman ahalinin de aynı hukuktan istifade etmeleri emniyesiyle tarafımızdan teyid ve temin edilecektir.

- Milli ve iktisadi inkişafatımız daire-i inkana girmek ve daha asri bir idare-i muntazama şeklinde tedvir-i umura muvaffak olabilmek için, her devlet gibi bizim de temin-i esbab ve inkişafatımızda istiklal ve serbesti-i tamme mazhar olmamız üssül-esas-ı hayat ve bekamızdır. ${ }^{14}$

Büyük Taarruz harekâtı, Mustafa Kemal, Fevzi ve İsmet Paşalar arasında tasarlanmıştır. Türk Bağımsızlık Savaşı'nın programı "Misak-ı Milli” ile çizilmiştir. Misak- Millîde, "Tam Bağımsızlık", olmazsa olmaz amaçlardan biri olarak belirlenmiştir. Askeri alanda kazanılan zaferler, diplomasi alanında taçlandırılarak yeni Türkiye devleti, dünyanın egemen güçlerine tam bağımsız devlet olarak

\footnotetext{
${ }_{13}$ Mustafa Budak, “Hangi Misak-1 Milli?”, Yeni Türkiye Misak-1 Milli Özel Sayısı, XXIII, S. 93, Yeni Türkiye Stratejik Araştırma Merkezi Yayınları, Ankara Ocak-Şubat 2017, s. 114.

${ }^{14}$ Misak-1 Milli metni ve tarihi değeri hakkında farklı değerlendirmeler için bk. Necati Ulunay Ucuzsatar, Atatürk'ün Jeopolitiği Misak-1 Milli ve Küresel Emperyalizm, Der Yay., İstanbul 2011; Ali Güler, Türk'ün Unutulan Yemini: Misak-1 Milli, İstanbul 2016.
} 
tanıttırılmıştır. Türk milletinin ilerlemesinin yolunu açan da "Tam Bağımsızlık" ve “Milli Egemenlik" ilkeleri olmuştur ${ }^{15}$.

27 Ağustos'ta Afyonkarahisar'ın kurtarılması tüm Anadolu' da büyük bir sevinç uyandırmıştır. Başta Ankara ve ona bağlı Haymana ve Ayaş, Konya-Ereğli, KarsSarıkamış, Adana, Mersin, İzmit ve Zonguldak'ta zafer gösterileri yapılmıştır. Hiç şüphesiz şehrin kurtuluşu en fazla Afyonkarahisar halkını sevindirmiştir. 27 Ağustos ikindi vaktinde Türk ordusu şehre girerken halk küçügünden büyügü̈ne, erkeğinden kadınına; askerlerin, subayların ayaklarına, ellerine sarılmış ve gözyaşlarını tutamamışlardır. Özellikle Başkumandan Mustafa Kemal Paşa'ya büyük sevgi gösterilerinde bulunulmuştur. Afyonkarahisar'a bağlı yerlerin de kısa süre içinde Yunanlılardan temizlenmesi halkı daha da mutlu etmiştir. Afyonkarahisar halkı 1 Eylül Cuma günü kurtuluşları için bir gösteri düzenlemiştir. İlk olarak Mevlevî Dergâhında şehitlerin ruhları için mevlit okutulmuş, ardından da cuma namazı kılınmıştır. Dini etkinlikler sonrasında halk Belediye Dairesi önünde toplanarak sevinç gösterilerinde bulunmuş ve Türk ordusunun kesin zaferi için dualar etmiştir. Afyonkarahisar'ın geri alınması üzerine Ankara'da da sevinç gösterileri yapılmıştır. İlk etkinlikler Haymana ve Ayaş'ta yapılmıştır. Buralarda Afyonkarahisar'ın kurtuluşu nedeniyle halk toplanarak sevinçlerini birbirleriyle paylaşmışlar, Türk ordusunun zaferleri için mevlit ve dualar okunmuştur ${ }^{16}$.

Yeni Türk devletinin kuruluşundan itibaren sürekli olarak devletin, Türkiye Büyük Millet Meclisi'nin ve hükümetin gündeminde bulunan, programlarında yer alan Misak-1 Milli'nin önemine daima vurgu yapılmış, özellikle dış politikada, Misak-1 Milli, gerçekleştirilmesi gereken bir belge olarak kaydedilmiştir. Bunun tezahürlerini Türk Milli Mücadelesinin pek çok safahatında görmek de mümkündür. Lozan Barış Konferansı'na giden Türk heyetine verilen 14 maddelik metinde birçok defa görmek de mümkündür, Lozan'dan sonra modern Türkiye Cumhuriyeti'nin pek çok politikalarında ve bugün yüzüncü yılına emin adımlarla giden Türkiye Cumhuriyeti'nde görmek de mümkündür. Görünen o ki, Türkiye Cumhuriyeti var oldukça, Misak-1 Milli de var olacak, payidar olacaktır ${ }^{17}$.

Atatürk'ün Türk tarihi içindeki en önemli rolü, imparatorluktan milli devlete geçişi sağlamak olmuştur. Bu bakımdan Atatürk'ün daha İttihat ve Terakki içindeyken bile "Misak-1 Milli" sinırları üzerinde ssrarla durması ve sonradan yapılacak Milli Mücadele'yi de bu çerçeveden mütalaa etmesi, onda bir "milli vatan" kavramının varlı̆̆ını göstermektedir ${ }^{18}$.

Birinci Dünya Harbi'nden sonra meydana gelen gelişmeler Mustafa Kemal'i haklı çıkartmış ve onun "milli vatan" anlayışını benimsemekle ne kadar gerçekçi

\footnotetext{
${ }^{15}$ Saime Yüceer, a.g.m., s. 141.

${ }^{16}$ Uğur Üçüncü, “Türk Kamuoyunda Büyük Taarruz”, Afyon Kocatepe Üniversitesi Sosyal Bilimler Enstitüsü Tarih Anabilim Dalı Doktora Tezi, Afyonkarahisar 2010, s. 197.

${ }_{17}$ Enis Şahin, "Yakın Dönem Türk Tarihinin Kızıl Elması: Misak-1 Milli", Yeni Türkiye Misak-1 Milli Özel Sayısı, XXIII, S. 93, Yeni Türkiye Stratejik Araştırma Merkezi Yayınları, Ankara Ocak-Şubat 2017, s. 50.

18 Ali Güler, “ Misak-1 Millînin Alt Yapısı: Milli Vatan Düşüncesi”, Yeni Türkiye Misak-1 Milli Özel Sayısı, XXIII, S. 93, Yeni Türkiye Stratejik Araştırma Merkezi Yayınları, Ankara Ocak-Şubat 2017, s.160.
} 
olduğunu göstermiştir. Artık onun çeşitli vesilelerle açıkladığı bu düşünceleri Milli Mücadele' nin tarihi gelişimi içinde fiili, hukuki ve siyasi bir tez haline gelmiştir ${ }^{19}$.

Kısacası; Türk milletinin "haysiyetli ve şerefli bir millet olarak" yaşama esasına dayanan Milli Mücadele'nin mihenk taşı, Misak-1 Milli kararları olmuştur. Milli Mücadele'nin her devresinde "nihai hedefin Misak-1 Milli sinırları" dahilinde tam bağımsız yaşamak olduğu ısrarla dünya kamuoyuna duyurulmuş, yürüyüş yolundaki engellerin üzerine imanla, kararlılıkla ve tereddütsüz gidilmiştir ${ }^{20}$.

1922 yılında askeri zafer sonrasında da diplomasi mücadelesinin de eksenini yine Misak-1 Milli kararları teşkil etmiştir. Gösterilen hassasiyete rağmen Milli Mücadele içinde feda edilen Batum'a, Lozan'da yenileri eklenmek durumunda kalınmıştır ${ }^{21}$.

İstiklal Harbi'nin çerçevesini belirleyen bu belge aynı zamanda Türkiye Cumhuriyeti devletinin temellerini de oluşturmuştur. Misak-1 Milli'de ortaya koyulan sınırlar, yeni Türk devletinin sosyolojik biçimlenmesine yol açtığı gibi "Ne Mutlu Türküm Diyene" anlayışının gelişmesine de zemin hazırlamıştır. Bu anlayış bir kültürel birlikteliği ifade etmektedir ${ }^{22}$.

\section{B. TURIZM ve EKOTURIZM}

\section{Turizm Kavramı ve Türleri}

Coğrafi çevre, insanların yaşamlarını sürdürebilmek için çeşitli amaçlarla kullandığı, insanı etkilediği kadar kendisinin de etkilendiği, doğal ve kültürel elemanlardan ve karşılıklı ilişkilerden oluşan bütünsel bir mekândır. Bu mekâna en fazla gereksinim duyan, hatta onun varlık nedeni olan sektör "turizm" dir ${ }^{23}$.

Günümüzde turizmin yarattığı ekonomik, sosyal, kültürel ve politik etkiler, özellikle uluslararası ekonomik ve politik ilişkilerde oynadığı rol giderek önem kazanmaktadır. Bu durum, yalnız uluslararası turizm hareketinden büyük pay alan gelişmiş ülkelerde değil, aynı zamanda gelişmekte olan ülkelerde de turizme verilen önemi artırmaktadır. Turizm, uluslararası ölçekte geniş istihdam olanakları yaratan bir sektördür ve dünyada yaklaşık 300 milyon insana iş imkanı sağlamaktadır. Başka bir ifadeyle; dünyada her 16 çalışandan biri turizm sektöründedir ve tüm uluslararası sermaye yatırımlarının yaklaşık \%7'si turizm alanına yapılmaktadır. Bu bağlamda

\footnotetext{
${ }^{19}$ Güler, a.g.m., s.162.

${ }^{20}$ Turan Akkoyun, "Bağımsızlı̆̆ın Fedakarlık, Miras ve Sorumluluk Ahidi: Misak-ı Milli”, Yeni Türkiye Misak- Milli Özel Sayısı, XXIII, S. 93, Yeni Türkiye Stratejik Araştırma Merkezi Yayınları, Ankara OcakŞubat 2017, s.167.

${ }^{21}$ Akkoyun, a.g.m., s. 172.

${ }^{22}$ Hikmet Öksüz, "Misak-1 Milli: Bir Reel Politik Yansıması”, Yeni Türkiye Misak-1 Milli Özel Sayısı, XXIII, S. 93, Yeni Türkiye Stratejik Araştırma Merkezi Yayınları, Ankara Ocak-Şubat 2017, s. 691.

${ }^{23}$ Mehmet Ali Özdemir- İsmail Kervankıran, “Turizm ve Turizmin Etkileri Konusunda Yerel halkın Yaklaşımlarının Belirlenmesi: Afyonkarahisar Örneği", Marmara Coğrafya Dergisi, S. 24, Temmuz - 2011, s. 2.
} 
dünyada ve ülkemizde turizme verilen önem artmakta, turizm eğilimleri çeşitlilik kazanmakta, yeni yerler yeni turizm türleri insanların ilgisini çekmektedir ${ }^{24}$.

Bir toplumun demografik yapısı turizmi etkilemekte; toplumun çeşitli kesimleri arasında turizme katılma düzeyi bakımından ayrılıklar bulunmaktadır. Turizmin gelişmesi ile birlikte, turist - yerli ilişkileri, turistlerin davranışları ve birbiriyle ilişkileri, önemli toplumsal olaylar durumuna gelmiştir. Yerlilerin, turistlere, yakın ve sıcak biçimde davranması, onlara konukseverlik göstermesi, turistleri gittikleri ülkeye bağlar; orada daha uzun süre kalmalarını sağlamaktadır. Ülkelerine döndüklerinde, olumlu eleştirilerde bulunarak, başkalarının da oraya gitmelerini sağlamalarına neden olabilirler ${ }^{25}$.

\section{Ekoturizm Terimi}

Ekoturizm, sürdürülebilir turizmin bir alt bölümünü oluşturmaktadır. Bazen sürdürülebilir turizmle eş anlamlı olarak kullanılmakla birlikte, Ekoturizm sürdürülebilir turizm şekillerinden biridir. Turizm açısından sürdürülebilirlik kavramı, turizmin kaynağ1 olan doğal, tarihi, kültürel, sosyal ve estetik değerlerin korunup geliştirilerek çekiciliklerinin devamının sağlanmasını ifade etmektedir ${ }^{26}$.

Turizmin bölgeye etkisi birçok açıdan olabilmektedir. Ekonomik açıdan gelişmesine, çevrenin düzenlemelerine, kültürün artmasına, doğal ve kültürel değerlerin korunmasına neden olmaktadır. Çevresel başlıca olumlu etkiler doğal, arkeolojik ve tarihi alanların korunması, çevre kalitesinin iyileştirilmesi, çevrenin değerinin artırılması, altyapı olanaklarının geliştirilmesi, çevrenin ön plana çıkarılması; başlıca olumsuz etkiler su, hava ve gürültü kirlilikleri, görsel kirlenme, katı atıklar, ekolojik bozulmalar ve biyolojik çeşitliliğin azalması, arkeolojik ve tarihi alanların zarar görmesi ile alan kullanım sorunlarıdır. Sosyo-ekonomik olumlu etkiler ekonomik yararlar, kültürel mirasın korunması, kültürel değerlerin yenilenmesi, karşılıklı kültürel değişim; olumsuz etkiler potansiyel ekonomik yararların kaybolması, ekonomi ve istihdam bozulmaları ve aşırı kalabalık olumsuz kültürel etkiler ve sosyal sorunlardir ${ }^{27}$.

Ekoturizm geniş alanlardaki ekolojik yapıyla birlikte düşünülmesi gereken bir turizm türü olduğundan, bütün turizm çeşitlerinde bunların dengesini bozacak müdahalelerden kaçınılması ana amaçtır. Ekoturizmde, kitle turizminin aksine turist sayısını aza indirmek ve turizmi yıl içinde yaymak, doğal çevreye yapılan baskıyı azaltmak, tahribatı düzeltmeye değil, önlemeye yönelik planlar yapmak ve uzun vadeli ekonomik çıkarları gözetmek daha ön plandadır ${ }^{28}$.

Ekoturizmin olumlu ekonomik etkileri; yerelde yaşayanlar için istihdam olanaklarının artması ilave bölgesel gelirler yani ekoturizm faaliyetlerinden elde edilen

\footnotetext{
${ }^{24}$ Özdemir- Kervankıran, a.g.m., s.3.

${ }^{25}$ Özdemir- Kervankıran, a.g.m., s.19.

${ }^{26}$ Nazan Kuter- H.Emre Ünal, "Sürdürülebilirlik Kapsamında Ekoturizmin Çevresel, Ekonomik ve SosyoKültürel Etkileri", Kastamonu Üni. Orman Fakültesi Dergisi, 2009, 9 (2), s. 147.

${ }^{27 O ̈ z d e m i r-~ K e r v a n k ı r a n, ~ a . g . m ., ~ s . ~} 4$.

${ }^{28}$ Kuter- Ünal, a.g.m., s. 150.
} 
direk gelirler ve parklara giriş ücretleri; yöresel sanatlar ve zanaatlar ile restoranlar, oteller ve buralardan gelen vergilerle bulunduğu bölgeye gelir sağlamaktadır. Dünyada Ekoturizmin geliştiğini gösteren olumlu örnekler bulunmaktadır bunlar arasında; 1993 yılında Dominik Hükümeti'nin teşvikiyle Karayip'liler doğal ve kültürel kaynaklarının korunması ve ekonomik teşvik sağlanması amacıyla Ekoturizmi geliştirmek için bir yöntem planı oluşturmuşlardır. Bu plan yerel halkın katılımı ile onların kültürü, çevresi ve yaşam şartlarını geliştirecek şekilde kaynakların yönetimini sağlamıştır. Böylece yerel halk ürettikleri sepetler, el çantaları gibi el sanatları ve yerel tarım ürünlerinden önemli bir gelir elde etmeye başlamıştır. Örneğin bir el sanatları işçisi aylık 320 Amerikan Doları gelir elde etmekte ve Dominik Cumhuriyeti'nin gayri safi milli hasılasına yılda 1000 Amerikan Doları katkı sağlamaktadır. Ayrıca turizm, yerel halka kendilerine ait mülklerde küçük konaklama olanakları sunmaları, taksi şoförlüğü, tur rehberliği gibi yeni istihdam olanakları yaratmıştır. Ekoturizmin gelişme göstermesiyle savaş alanları turizminin de önemi artmaktadır. Ekoturizmin olumsuz ekonomik etkilerinden biri yerel enflasyona sebep olmasıdır. Yerel toplumun Ekoturizme yönelik beklentilerinin sinırlı olması, onların doğal ve kültürel kaynaklarını koruma konusundaki isteklerini azaltmak gibi bir sonucu da beraberinde getirmektedir. Yöredeki oteller ve benzeri tesislerin su ve enerji gibi kaynakları aşırı tüketmeleri, bölgedeki fiyatları arttırmakta, elektrik ve su kesintilerine neden olabilmektedir ${ }^{29}$.

\section{BAŞKOMUTANLIK MEYDAN MUHAREBESI'NIN AFYONKARAHISAR EKOTURIZMI'NE ETKISİ}

Afyonkarahisar, turizm potansiyeli yönünden fakir gibi görünse de aslında yöremize gelecek yerli ve yabancı turistlerin deniz dışında aranan pek çok güzelliği bulabilecekleri bir bölgedir. Afyon; müzeleriyle, dinlenme ve mesire yerleriyle, şifalı sularının bulunduğu kaplıcalarıyla turistik açıdan önemli doğal güzelliklere sahip bir şehirdir.

Afyonkarahisar, tarihte geçmişteki yeri kadar bundan daha önemlisi Türkiye Cumhuriyet tarihinde büyük önem taşımaktadır. Şanlı Türk Askeri cengâverliğini her savaşta ortaya koymuştur. Öyle ki bir Çanakkale'de kendinden kıyaslanamayacak kadar büyük ve güçlü düşmanı akıl almaz bir biçimde dize getirmiş, pes ettirmiştir. Bu yönden Çanakkale önemlidir. Çanakkale düşmanın hiç aklından çıkmaz. Her seferinde Çanakkale'nin nasıl bir yer olduğu görmek istenir. Ama Afyonkarahisar, Türkiye Cumhuriyeti Devleti açısından daha da önemlidir. Zira Türk Kurtuluş Savaşı'nın verildiği, Büyük Komutan, Mustafa Kemal komutasındaki şanlı Türk Askeri'nin Türkiye Cumhuriyeti ilk kurtuluş destanını yazdığı yer Afyonkarahisar topraklarıdır. Dumlupınar, Kocatepe ve Afyonkarahisar Türk Askeri'nin kahramanlığıyla özdeşleşmiş ve destanlaşmıştır. İslam'ın Kâbe'si ne ise Türkiye Cumhuriyetinin

\footnotetext{
${ }^{29}$ Kuter- Ünal, a.g.m., s. 152,153.
} 
varoluşu açısından Afyon'un önemi de o'dur. Bu önem turizm sahasında değerlendirilmesi gereken büyük potansiyeldir ${ }^{30}$.

Afyonkarahisar'ın, Boğazlar kadar önemli bir stratejik konumu vardır. Türk Ordusunu Akdeniz'e Ege'ye ulaştıracak bir geçittir. Kocatepe'de bir ulusun yazgısı yeniden çizilmiştir. Türk'ün talihinin güldügü, Büyük Taarruzla ilk kurtarılan şehirdir Afyon. Türk Ulusunun, Milli Mücadele'de, Afyon'da, Dumlupınar'da yarattığı destan, yeni Türk Devletinin müjdecisi Türk Ulusu için yeniden bir "Ergenekon" bir çıkış, kurtuluş yolu olmuştur ${ }^{31}$.

Mustafa Kemal Paşa'nın yakın arkadaşlarıyla İstanbul'da yaptığı görüşmelerden çıkan Milli Mücadele düşüncesi, kurtuluşa yönelik bir yöntem üzerinde yoğunlaşıyordu. Mütareke ve ardından işgallerin başlaması, millete şüphesiz ki yeni ve pek çok yöntemi de düşündürmeye başlamıştır. Mustafa Kemal Paşa'nın önderliğinde sürdürülen Milli Mücadele' de, artık "kendisini hissettirmeyen ve yıkılma aşamasında bulunan" devletin ve etkisiz hükümetin yerine, millet kendi mukadderatını kendi eline alması başlıca prensip olarak kabul edilmiştir. Vatan coğrafyası ile ilgili en yaygın ve belki de "en zorunlu" düşünce ise, Mondros Mütarekesi ile çizilen sınırların korunmasının, mevcut şartların "asgarisi" olarak tebellü̆ğ ettiği gerçeğidir ${ }^{32}$.

Ulusal Kurtuluş Savaşı olarak da nitelenen Türk Milli Mücadelesi'dir. Anadolu'da yapılacak bir "var oluş-yok oluş" mücadelesi olan Mücadele-i Milliye başladığında millet nezdindeki en büyük endişeyi yine beka sorunu teşkil etmektedir. Zaten milleti harekete geçiren asıl faktör de "yarınının ne olacağı endişesi" olmuştur ${ }^{33}$. Afyonkarahisar ilinin bu denli önem arz etmesi bu şehre olan ilgiyi de arttırmıştır. Bu nedenle, savaş alanları sahasının sürdürülebilir Ekoturizm alanı haline getirmek önemlidir.

Afyonkarahisar ilinin, bu kültürel çekiciliklerinden biri de kentsel sit alanı olmasıdır. Sit alanı yaklaşık 23 hektarlık bir alanı ve Kale çevresinde 20 mahalleyi kapsamaktadır. Alanda, geleneksel Türk şehrinin bütün özelliklerini bulmak mümkündür. Afyonkarahisar kalesi bir diğer turizm alanıdır. Başkomutanlık Milli Parkı, Gelibolu Yarımadası Tarihi Milli Parkı gibi, savaş alanları turizmi açısından ülkemizdeki önemli alanlardan biridir. Savaş alanları siperler ve diğer harp izleri, şehitlikler ve anıtlar milli parkın en önemli kaynağını oluşturmaktadır. Siperler ve harp izleri özellikle Kocatepe bölümünde yoğunluk kazanmışlardır. Kültürel varlıkların sergilendiği açık veya kapalı mekânlar olan müzeler, şehirdeki kültürel çekiciliklerin bir başka unsurudur ${ }^{34}$.

\footnotetext{
${ }^{30}$ Mevlüt Palta, " Afyonun Turizm Potansiyeli", Tarih İçinde Afyon 1982, Afyon Müzelerini Eski Eserlerini ve Güzel Sanatlarını Sevenler Derneği Yayını-2, Özen Matbaası, Afyon 1983 s. 63.

${ }^{31}$ Taşyürek, a.g.m., s. 46.

32 Şahin, a.g.m., s. 40.

33 Şahin, a.g.m., s.42.

34 Özdemir- Kervankıran, a.g.m., s. 10.
} 


\section{SONUÇ}

26 Ağustosta başlayan Büyük Taarruz ve 30 ağustos Dumlupınar Başkumandanlık Meydan Savaşını safha safha incelerken Afyonkarahisar'ın Milli Mücadele' deki yeri ve önemi daha iyi anlaşılmaktadır.

Dünyada her yıl milyonlarca insan ya kendi ülkelerinde ya da farklı ülkelere seyahate çıkmaktadırlar. Yeni yerler keşfetmek, gezip görme, eğlenme, dinlenme, farklı kültürleri ve farklı mekânları tanımak amacıyla, turizm etkinliklerine katılan kişi sayısı her geçen gün artmaktadır. Önceleri kıyı kesimlerinde gelişme gösteren turizm faaliyetleri, son yıllarda iç kesimlere, farklı doğal ve tarihi güzelliklerin bulunduğu yörelere doğru ilerlemektedir. Bu illerden biri olan Afyonkarahisar, sahip olduğu termal kaynakları, doğal ve kültürel değerleri, tarihi güzellikleri ile turizm yatırımlarının artmaya ve turizm faaliyetlerinin cazip hale gelmeye başladığı bir il konumuna gelmiştir.

Afyonkarahisar doğal güzellikleri bakımından tarihi ve kültürel bir öneme sahiptir. İlin sosyal ve ekonomik olarak canlanması, gelişmesi ve bölgesel değişikliklerin oluşmasında turizmin rolü büyüktür. Gelişme safhasında olan Afyonkarahisar, turizmin çevreye, sosyo- ekonomik yapıya, tarihi ve kültürel kaynaklara etkisi yavaş yavaş ortaya çıkmaya başladığı görülmektedir. Afyonkarahisar ilinde ekonomik, çevresel ve sosyo-kültürel bakımdan turizmin etkilerinin değerlendirilmesi, turizmin Afyonkarahisar'daki sürdürülebilirliği ve ekonomik gelir sağlaması bakımından önemlidir. Burada yerel halkında turizme ve turistlere bakış açısının da değerlendirilmesi gerekir. Olumsuz yaklaşımları bir kenara bırakırsak iş olanağı sağlaması bakımından değerlendirildiğinde Afyonkarahisar ili için turizmin yeri farklı bir öneme sahiptir. Bir bölgenin kalkınması için özellikle savaş alanı bölgelerinin değerlendirilmesi, tarihi; yerinde ve doğru bir şekilde öğrenmek sebebiyle, insanların bu konuda bilinçlendirilmesi gerekir. İlin doğal, tarihi ve kültürel potansiyelinin turizmin gelişimine müsait olduğundan turizm yatırımlarının artması gerekmektedir.

\section{KAYNAKÇA}

\section{Araş̧ıิırmalar}

Akkoyun, T. (16.11.2015-29.02.2016). Başkomutanlık Millî Parkı'nın Tarihî Temeli Büyük Taarruz Sahası: Hazırlık, Başlaması ve Başkumandanlık Meydan Muharebesi. Başkomutan Millî Parkı Bilirkişiliği, Afyonkarahisar-Kütahya-Ankara, 1-12.

Güler, M. vd. (16.11.2015-29.2.2016). Başkomutan Millî Parkı Bilirkişiliği Araştırma Sonuç Raporu, Afyonkarahisar-Kütahya-Ankara, 42-43.

Karazeybek, M. (16.11.2015-29.2.2016). Arşiv Vesikalarına Göre Büyük Taarruz Savaş Alanları ve Millî Park Sınırlarının Belirlenmesi Hususunun Değerlendirilmesi. Başkomutan Millî Parkı Bilirkişiliği, Afyonkarahisar-Kütahya-Ankara, 13-34.

Kurt, Ü. E. (16.11.2015-29.2.2016). Başkomutan Tarihi Millî Parkı Yüzey Araştırması. Başkomutan Millî Parkı Bilirkişiliği, Afyonkarahisar-Kütahya-Ankara, 34-41. 


\section{Kitaplar, Makaleler}

Akkoyun, T. (Ocak-Şubat 2017). Bağımsızlığın Fedakarlık, Miras ve Sorumluluk Ahidi: Misak-1 Milli, Yeni Türkiye Misak- Milli Özel Sayısı, 23 (93): 163-174.

Alaeddinoğlu, F. (2010). Kocatepe'nin Türk Kültür Turizmi Açısından Önemi. Gürsoy Şahin (Ed.), Atatürk ve Büyük Taarruz Kahramanlarına Armă̆an (s. 413-452). Afyonkarahisar.

Arslan, Y. (Mayıs 2005). Erdek ve Çevresinin Ekoturizm Açısından Değerlendirilmesi, Balıkesir Üniversitesi Sosyal Bilimler Enstitüsü Dergisi, 8 (13): 29-53.

Artuç, İ. (2008). Başkomutan Meydan Muharebesi, Büyük Taarruz. İstanbul: Kastas Yayınları.

Budak, M. (Ocak-Şubat 2017). Hangi Misak-ı Milli?, Yeni Türkiye Misak-ı Milli Özel Sayısı, 23 (93): 114-121.

Görgülü, İ. (1992). Büyük Taarruz, Ankara: Genelkurmay Yayınları.

Güler, A. (2016). Türk'ün Unutulan Yemini: Misak-ı Milli, İstanbul. (Ocak-Şubat 2017). Misak-1 Millînin Alt Yapısı: Milli Vatan Düşüncesi, Yeni Türkiye Misak-ı Milli Özel Sayısı, 23 (93): 160-162.

İçlek G., Gül A. ve Metin K. (2017). Ayazin Örenyeri'nin Ekoturizm Açısından Değerlendirilmesi, Karabük Üniversitesi Sosyal Bilimler Enstitüsü Dergisi, Özel Sayı 3: 145159.

Kuter, N. ve Ünal, H. E. (2009). Sürdürülebilirlik Kapsamında Ekoturizmin Çevresel, Ekonomik ve Sosyo-Kültürel Etkileri, Kastamonu Üniversitesi Orman Fakültesi Dergisi, 9 (2): 146-156.

Kütükoğlu, M. (2011). Tarih Araştırmalarında Usul, Ankara: Türk Tarih Kurumu Yayınları.

Oflazoğlu, A. T. (2011). Mütarekeden Büyük Taarruza, İstanbul: İz Yayınları.

Öksüz, H. (Ocak-Şubat 2017). Misak-1 Millinin Günümüze Yansımaları, Yeni Türkiye Misak-ı Milli Özel Sayısı, 23 (93): 680-692.

Özdemir, M. A. ve Kervankıran, İ. (Temmuz 2011). Turizm ve Turizmin Etkileri Konusunda Yerel halkın Yaklaşımlarının Belirlenmesi: Afyonkarahisar Örneği, Marmara Coğrafya Dergisi, 24: 1-25.

Özey, R. (Ocak-Şubat 2017). Misak-ı Milli Coğrafyası Üzerine Genel Değerlendirme, Yeni Türkiye Misak-ı Milli Özel Sayısı, 23 (93): 771-788.

Palta, M. (1983). Afyonun Turizm Potansiyeli, Tarih İçinde Afyon 1982, 63-65.

Selek, S. (1997). Milli Mücadele: Büyük Taarruz'dan İzmir'e, İstanbul: Cumhuriyet Gazetesi Yayınları.

Şahin, E. (Ocak-Şubat 2017). Yakın Dönem Türk Tarihinin Kızıl Elması: Misak-1 Milli, Yeni Türkiye Misak-ı Milli Özel Sayısı, 23 (93): 38-51.

Taşyürek, A. (1983). Ulusal Kurtuluş Savaşında ve Cumhuriyet Döneminde Afyon, Tarih İçinde Afyon 1982, 46-52.

Türkmen, Z. (2010). Büyük Taarruz Harekatı. Gürsoy Şahin (Ed.), Atatürk ve Büyük Taarruz Kahramanlarına Armağan (s. 79-148). Afyonkarahisar.

Ucuzsatar, N. U. (2011). Atatürk'ün Jeopolitiği Misak-ı Milli ve Küresel Emperyalizm, İstanbul: Der Yayınları. 
Üçüncü, U. (2010). Türk Kamuoyunda Büyük Taarruz (Basılmamış Doktora Tezi). Afyonkarahisar: Afyon Kocatepe Üniversitesi Sosyal Bilimler Enstitüsü Tarih Anabilim Dalı.

(2012). Büyük Taarruz, İstanbul: Altın Post Yayınları.

Yüceer, S. (Ocak-Şubat 2017). Bir Ütopyanın Gerçekleşmesi: Tam Bağımsız Türkiye ve Misak-I Milli, Yeni Türkiye Misak-ı Milli Özel Sayısı, 23 (93): 141-148. 